\title{
Notas sobre o caso Altazor (precedidas de deriva teórica)
}

\author{
Daniel Glaydson Ribeiro
}

\begin{abstract}
Doutorando em Teoria Literária
e Literatura Comparada pela

Universidade de São Paulo

- USP. Mestre em Língua

Espanhola e Literaturas

Espanhola e Hispano-Americana pela USP.
\end{abstract}


CARACOL 3 / VÁRIA

Palavras-chave: Poesia chile-

na; Vanguardas; Linguagem e

história; Verso épico moderno.

KEYWORDS: Chilean poetry;

Vanguards; Language and his-

tory; Modern epic poetry.
Resumo: Precedido por uma breve deriva teórica a

respeito do grande poeta e suas condições de apa-

recimento (míticas e/ou mitológicas) - e mais uma

hipótese diferencial para a lírica e a épica -, isto é um

ensaio empenhado na compreensão da narrativa Altazor,

oitenta anos depois sua publicação.

ABSTRACT: Preceded by a brief theoretical drifting about

the great poet and the conditions of its appearance

(mythic and/or mythological) - and also a differential

hypothesis about the lyric and the epic -, this is an essay

engaged in comprehending the narrative entitled Altazor,

eighty years after its publication. 
Notas sobre o caso Altazor (PRecedidas de deriva teórica)

Daniel Glaydson Ribeiro

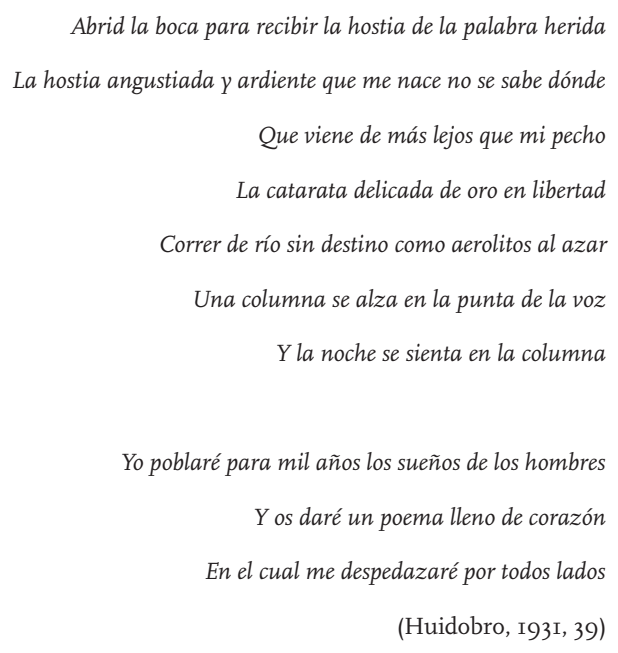

O GRANDE POETA, no sentido do narrador de uma totalidade em sua origem, é uma espécie de meta-mito. Ele precisa estar além do mito para poder dizêlo, para pronunciá-lo ou escriturá-lo, e assim regressar ao mito, glorificando-o e atualizando-o. Assim como a "metafísica é o perguntar além do ente para recuperá-lo, enquanto tal e em sua totalidade, para a compreensão" (Heidegger, I969, 39), uma fala meta-mítica deve ser o perguntar além do mito para recuperá-lo, enquanto tal e em sua totalidade, para a compreensão (e geralmente para a execução, já que o mito é um discurso ordenador).

Quando o grande poeta se localiza ingenuamente dentro da paisagem narrada, comunicando daí toda uma potência de verdade sagrada, a impressão é de que não há sequer um perguntar além, mas apenas um deixar falar através de si. Afirmação pura e solene que constrói uma ponte no tempo, ao narrá-lo, e assim lhe concede, ou melhor, demonstra a unidade - entre a origem e o agora 
da narração (um agora que deseja ardentemente repetir-se: que alguém narre outra vez). Este não-perguntar íntimo do grande poeta talvez nos lembre do jovem Lukács, quando escreve deslumbrado que "o caráter inatingível e inacessível de Homero - e a rigor apenas os seus poemas são epopéias - decorre do fato de ele ter encontrado a resposta antes que a marcha do espírito na história permitisse formular a pergunta" $(2000,27)$.

Para a tradição estética romântica, o momento ideal do épico, e logo do grande poeta, é aquele em que a imanência já é, por si só, a transcendência. Contra a afirmação fatalista de tal corrente filosófica no que tange à morte da epopeia e, em última instância, da própria arte, a transcendência-imanente é possível de ser lida, com rigor, no primeiro Whitman. Num momento tal, só a escritura mítica pode existir. Já a mitológica, que é, de fato, um perguntar além, ainda não.

Escritura mítica e escritura mitológica são tipos relativamente instáveis de epopeia.

\section{HIPÓTESE}

O poeta lírico escreve o espaço no tempo da linguagem. O eu pode ser todo o espaço/todo o espaço pode estar no eu. O poema lírico comunica a transcendência individual; é a escritura de uma instância voltada a uma outra instância.

O poeta épico narra o tempo no espaço da linguagem. O tempo transcorre para o eu/o eu retroalimenta, ao narrar, o tempo. A epopeia representa a imanência coletiva; é a escritura de uma existência voltada a uma outra existência.

- A transcendência individual e a imanência coletiva não constituem uma dicotomia.

- Essa outra existência, essa outra instância, será sempre o leitor, numa disposição específica. O gênero discursivo é um astrolábio. 
Notas sobre o caso Altazor (PRECEDIDAs de DERIVA teórica)

Daniel Glaydson Ribeiro

\section{EXEGESE}

Há pouco, disse que a narrativa do grande poeta constrói uma ponte no tempo, ao narrá-lo. Esta ponte, o monumento espacial da metáfora, é exatamente a linguagem. Altazor, durante sua pronúncia, detém-se olhando a ponte ao ser construída, detém-se para estudar os mecanismos de sua própria construção em simultaneidade, em tautocronia. A narrativa mítica que ele tem a proferir desta vez - considerando que o grande poeta, como todo narrador, é sempre uma continuidade, um diálogo no tempo - é então, sua narrativa mítica, a própria linguagem (a ponte, o espaço que sustenta o tempo, tornando possível a travessia), e ao refletir ou expressar a linguagem como mito (pois é aí que o épico radica), o poema segue rumo à fala mais originária, que não é somente a comunicação do mito, mas já ela própria, a fala, o mito. Nisto reside todo o tempo que transcorre para o narrador, e que ele, ao narrar esta vez, retroalimenta.

Este vínculo originário entre a consciência lingüística e a mítico-religiosa expressa-se, sobretudo, no fato de que todas as formações verbais aparecem outrossim como entidades míticas, providas de determinados poderes míticos, e de que a Palavra se converte numa espécie de arquipotência, onde radica todo o ser e todo acontecer. (Cassirer, 2006,64 , grifo meu)

Por isso, Altazor sabe que:

Hay palabras que tienen sombra de árbol

Otras que tienen atmósfera de astros

Hay vocablos que tienen fuego de rayos

$Y$ que incendian donde caen

Otros que se congelan en la lengua $y$ se rompen al salir

Como esos cristales alados y fatídicos 
Mas o Canto I é o tempo da angústia e da ira; é como a selva escura. Logo, é possível que os versos seguintes a estes, na mesma estrofe, sejam:

Altazor desconfía de las palabras

Desconfía del ardid ceremonioso

Y de la poesía

Trampas

Trampas de luz y cascadas lujosas

Trampas de perla y de lámpara acuática

Anda como los ciegos con sus ojos de piedra

Presintiendo el abismo a todo paso (I93I, 40)

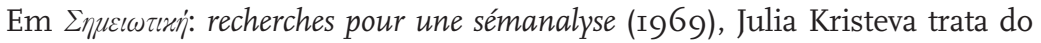
monologismo épico, dentro daquela chave histórico-filosófica (e romântico-idealista) que concebe a existência pretérita de um "estado épico" - o mundo ingenuamente poético, o paraíso perdido da integração entre o homem e a natureza, entre o ser e o absoluto, quando habitava entre os homens a serenidade moral, a sinceridade ética - e que, aliás, concebe-o para situar-se como a diferença, como o outro lado de tal "estado" primitivo, a lingüista conclui que a crença, "au sens propre du mot”, é inerente à lógica épica, em sua idealidade sincrética. Daí, o monologismo: trata(va)-se da Voz, indiscutivelmente. Mas em Altazor, o rapsodo vanguardista, instalou-se a dúvida, a descrença da crença, na expressão de Feuerbach; o grande poeta desconfia das palavras, desconfia do ardil cerimonioso e da poesia, armadilhas de luz e cascatas luxuosas. Instala-se uma fissura de grandes proporções a partir do momento em que o próprio poeta não se entrega mais, sem reservas, à linguagem - é uma fissura entre o som e o sentido, entre 
Notas sobre o caso Altazor (precedidas de deriva teórica)

Daniel Glaydson Ribeiro

a palavra e a prática. Nos termos da linguística estrutural, trata-se do fim do sincretismo. Conforme Kristeva, "lépique qui se structure à la fin du syncrétisme met en évidence la double valeur du mot dans sa période post-syncrétique: parole d'un sujet ('je') traversé inévitablement par le langage, porteur de concret et d'universel, d'individuel et de collectif' (1969, I60, I59). Por isso, o dialogismo: a irrupção de vozes que adentram inevitavelmente, que perguntam e provocam, que contra-dizem, que põem em jogo a própria identidade da minha voz, a voz do sujeito.

O problema da desconfiança de Altazor em relação à linguagem se relaciona singularmente com uma outra desconfiança, a que o leitor moderno precisa assumir frente aos perversos narradores da ficção novecentista. A questão é colocada, nestes termos, por Wayne Booth em seu The rethoric of fiction (I96I), e discutida por Paul Ricoeur no terceiro tomo de Tempo e narrativa (1985). Enquanto Booth vê com maus olhos (poder-se-ia mesmo dizer, com certo moralismo) as estratégias narrativas que seduzem o leitor rumo ao desmoronamento, as quais ele detecta em grande parte dos romances modernos, Ricoeur prefere pensar no "distanciamento" que a narrativa moderna impõe ao leitor como a abertura para uma nova ética de leitura.

A função da literatura mais corrosiva pode ser contribuir para fazer aparecer um leitor de novo tipo, um leitor ele próprio desconfiado, porque a leitura cessa de ser uma viagem confiante feita em companhia de um narrador digno de confiança, e torna-se um combate com o autor implicado, um combate que o reconduz a si mesmo. (Ricoeur, I997, 282)

200 
As relações outrora tácitas entre o leitor e o narrador, entre a história e as provas documentais ${ }^{\mathrm{I}}$, entre o grande poeta e a linguagem, estão igualmente postas em jogo, ambas as partes dis-postas a reconfigurar-se. A desconfiança de Altazor perante a linguagem não o leva ao mero desmoronamento: ele flutua na e com a linguagem, ele paira nela, e sua viagem é então uma transa e um combate $^{2}$ com a poesia, que o reconduz a si mesmo, o sujeito poeta, e que daí o reconduz à própria poesia - à origem, o nexo de toda causalidade. A promessa, a anunciação de tudo isso, é feita desde sempre, como por exemplo, na estrofe seguinte à transcrita mais acima, a que termina com os versos:

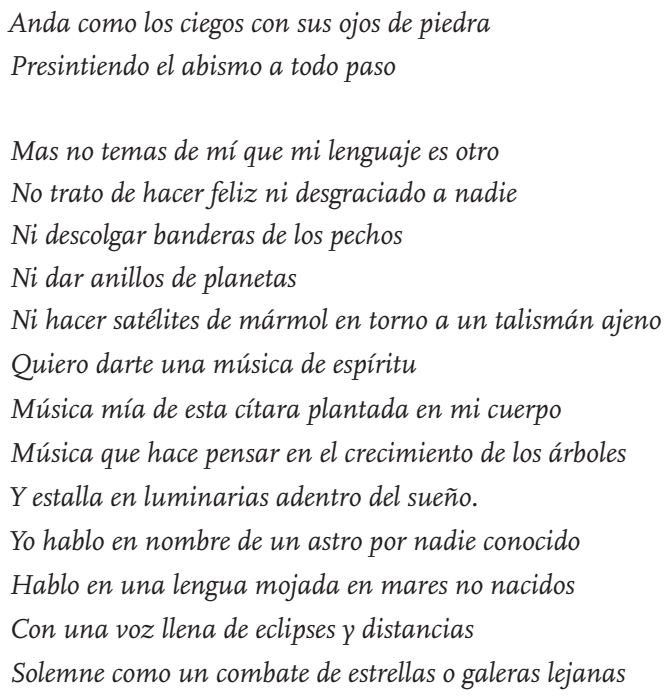

I “A questão de 'reliability' está para a narrativa de ficção assim como a prova documentária está para a historiografia" (Ricoeur, 1997, 280)

2 "Fidelidad al modelo heroico, guerra y amor, pero transpuesto al mundo del lenguaje: las criaturas con las que combate Altazor no son humanas, son vocablos. No chorrean sangre sino, en mezcla indescriptible, sonidos y sentidos." (Paz, I994, I80) 
Notas sobre o caso Altazor (precedidas de deriva teórica)

Daniel Glaydson Ribeiro

Una voz que se desfonda en la noche de las rocas

Una voz que da la vista a los ciegos atentos

Los ciegos escondidos al fondo de las casas

Como al fondo de sí mismos (1931, 40-41)

A cegueira, que acompanha Altazor desde a infância - no "Prefácio", sabemos que seu pai era cego e tinha mãos mais admiráveis que a noite -, permanece como uma obsessão no poeta, depois de órfão. Sua desconfiança tem a prudência dos cegos, pois o leva a pressentir o abismo a todo passo - e como diz Adorno, "nenhuma narrativa jamais participou da verdade sem ter encarado o abismo no qual mergulha a linguagem, quando esta pretende se transformar em nome e imagem" (2003, 5I), ou mais ainda, em significante e significado, em Signo indivisível. (Como um latido ou um ululo para o Abismo - "Perro del infinito trotando entre astros muertos / Perro lamiendo estrellas y recuerdos de estrella / Perro lamiendo tumbas / Quiero la eternidad como una paloma en mis manos" (I93I, 25). Não obstante, a outra linguagem que Altazor anuncia, uma música de espírito saída desta cítara plantada no corpo (a voz), pretende dar a vista, como fez Cristo, aos cegos atentos, escondidos ao fundo das casas como ao fundo de si mesmos. Altazor reconhece o poder mítico da palavra, mas há a desconfiança, o pressentimento do abismo (perante a poesia dos humores, das nações, dos ornamentos e outras mais), e há então a promessa da boa-nova, um evangelho (ou o silêncio, o próprio Abismo).

Enquanto a cegueira de Homero significa, em última instância, que seu discurso é ditado por Zeus; é por meio do olhar que Adão nomeia todas as coisas criadas por Deus. Erich Auerbach, em Mimesis - a representação da realidade na literatura ocidental (Mimesis - Dargestellte Wirklichkeit in der abendlandischen Literatur, I946), demonstra que Homero e o Velho Testamento são “igualmente 
épico[s]", mas guardam profundas diferenças, ou mesmo oposições. Altazor (não apenas o personagem Altazor, mas a obra) se alimenta destes dois "mundos de formas" (I97I, 5), a épica grega e a hebraica, e ainda de muitos outros - os mundos dos santos, dos trovadores, dos cavaleiros ungidos; os mundos barroco, romântico, modernista (em amplo espectro, de Darío a Nietzsche) e vanguardista - para lançar-se na imanência-transcendente, indizível e incalável (visível, cega, transvisível) de seu mundo.

Os Cantos III, IV e V são uma cruzada medieval contra a poesia e, por conseguinte, ao encontro dela mesma. Esta cruzada pergunta pelas imagens. Como se deve ver? Ou não ver? Renunciar às imagens ou amá-las? Daí a cruzada pergunta também, já que ela ocorre - ela cavalga e peleia - num espaço etéreo/ sideral que é sua metáfora da linguagem: como se deve ver a linguagem? Ou não vê-la? e então criar (ou desvendar) uma outra não vista (ainda, até então), uma língua molhada em mares não nascidos. Talvez esta seja a única saída para inventar-se (alcançar) uma totalidade cantável.

O olho está ancorado ao meio dos mundos, como se diz no Canto IV. "Por eso hay que cuidar el ojo precioso regalo del cerebro / El ojo anclado al medio de los mundos / Donde los buques se vienen a varar / ¿Mas si se enferma el ojo qué he de hacer? / ¿Qué haremos si han hecho mal de ojo al ojo?” (I931, 62). Situado entre coisa e palavra, o olho é o umbral da passagem entre um e outro, e mais do que isso: é o que prende um ao outro, segura-os, mantém-nos, ancora-os. No Canto III, que fora uma retomada, uma recaída da angústia (pode-se conjecturar um movimento binário que enforma Altazor, entre angústia e serenidade [Canto II], desconfiança e fé [Canto VII], um fluxo extremamente entrecortado), expressa-se uma vontade de levantar âncora, definitivamente: "Cadenas de miradas nos atan a la tierra / Romped romped tantas cadenas" (I93I, 54). Uma vontade de desprender-se do excesso de imagens, desprender-se mesmo das 
Notas sobre o caso Altazor (precedidas de deriva teórica)

Daniel Glaydson Ribeiro

imagens do mundo, pois não é a partir delas, atado a elas, que o poeta alcançará a totalidade - as imagens são tão efêmeras quanto o agora. O Canto III fala da extrema mutabilidade das coisas e imagina o que se verá amanhã: "Mañana el campo / Seguirá los galopes del caballo // La flor se comerá a la abeja / Porque el hangar será colmena [...] Los cuervos se harán planetas / Y tendrán plumas de hierba [...] Y el árbol se posará sobre la tórtola / Mientras las nubes se hacen roca" (I93I, 54-55). A indisposição do poeta com as imagens é mote para que se forjem outras.

O Canto III é basicamente o espaço da in-dis-posição generalizada: "Cortad todas las amarras / De río mar o de montaña // De espíritu y recuerdo / De ley agonizante $y$ sueño enfermo" (I93I, 54), e pouco adiante os versos já mui conhecidos, onde se investe sarcasticamente contra a musicalidade de um Valéry e sobretudo de um Lorca: "Poesía aún y poesía poesía / Poética poesía poesía / Poesía poética de poético poeta / Poesía / Demasíada poesía / Desde el arco-iris hasta el culo pianista de la vecina / Basta señora poesía bambina / Y todavía tiene barrotes en los ojos" (I93I, 56). Facilmente se pode acusar Altazor (e Huidobro, seu duplo) por uma iconoclastia obsessiva, compulsiva: sua artilharia aponta para todos os lados e contradiz-se sem escrúpulos. Antes se anunciara uma "música de espíritu”, agora já se devem cortar as amarras que nos atam ao espírito, às recordações, às leis, aos sonhos. Seu fervor crítico parece não deixar nada em pé no altar da poesia: despedaça a fanopeia e a melopeia. Como em toda cruzada, é preciso defender apenas o seu deus: a outra poesia - a essência do conhecimento deste seu deus é a pura negatividade. "Basta señora arpa de las bellas imágenes / De los furtivos comos iluminados / Otra cosa otra cosa buscamos" (I93I, 56). René de Costa assinala que a crítica aí se dirige ao beau comme, "el símil alógico sistematizado por Lautréamont” (1984, 202). Mais interessante é notar que a contradição não se restringe ao plano das ideias. Altazor vai compondo 
poesia nos moldes que estão sendo, simultaneamente, questionados. A passagem sobre os "comos iluminados" é um exemplo categórico, sobretudo pela potência dos versos alcançados - Altazor segue jogando e testando sua própria condição de grande poeta: "Sabemos posar un beso como una mirada / Plantar miradas como árboles / Enjaular árboles como pájaros / Regar pájaros como heliotropos [...] Desembarcar cometas como turistas / Embrujar turistas como serpientes" e ao fim: "Tripular crepúsculos como navíos / Descalzar un navío como un rey / Colgar reyes como auroras / Crucificar auroras como profetas / Etc. etc. etc." (I93I, 57). O Canto III fala da agonia do "último poeta", fala mesmo do "entierro de la poesía", mas dá a conhecer, de pronto, "el nuevo atleta", que "salta sobre la pista mágica / Jugando con magnéticas palabras / Caldeadas como la tierra cuando va a salir un volcán / Lanzando sortilegios de sus frases pájaro" (I93I, 58). A ideia do jogo não deve ser menosprezada, ou entendida como uma diminuição da tarefa, da função da poesia. Desde as Investigações filosóficas (Philosophische Untersuchungen, 1953) de Wittgenstein, passando pelo cinema de Antonioni, até Agamben em "O autor como gesto", a densidade do jogo nas relações humanas tem se mostrado abissal, ou, em outros termos, o jogo tem se tornado cada vez mais algo da ordem do Ser. O canto III remata sem meias palavras, brotadas de uma certa desesperança ativa: "Y puesto que debemos vivir y no nos suicidamos / Mientras vivamos juguemos / El simple sport de los vocablos / De la pura palabra Y nada más / Sin imagen limpia de joyas / (Las palabras tienen demasiada carga) / Un ritual de vocablos sin sombra" (I93I, 59).

O problema da pureza da palavra é algo nevrálgico no panorama huidobriano e altazoriano. Lembremos que, em I926, Mariátegui toma categoricamente a Huidobro para servir como mau exemplo de um poeta que, apesar de no seio das vanguardas, mantém a ideia "tan antigua y caduca" de que "el arte es independiente de la política" (I974, I23). O estigma dessa crítica focada 
Notas sobre o caso Altazor (precedidas de deriva teórica)

Daniel Glaydson Ribeiro

num pretenso alheamento de Huidobro em realação à realidade permanecerá como um alvo fácil para os detratores. No Canto general de Neruda, num poemeto intitulado "Los poetas celestes" é dirigida a Huidobro e até mesmo a Altazor. A história da crítica altazoriana, por sua vez, oscila entre considerar a obra como a culminância da teoria criacionista (i.e., a culminância da "pureza" da palavra, sendo isto seu alheamento do mundo) e, por outro lado, considerá-la como um desprendimento, uma ultrapassagem ou mesmo uma negação $0^{4}$ do criacionismo. Altazor é, a bem da verdade, irredutível a ambas dicotomias (entre criacionismo e não-criacionismo e entre palavra pura e palavra engajada). Primeiro seria preciso perguntar de que criacionismo se está falando com relação a Altazor: o criacionismo da década de igıo e primeira metade da seguinte, cujo ciclo se fecha com o livro Manifestes (I925), publicado por Huidobro em Paris, onde se parece pregar, de fato, uma metafísica da criação artística - "[...] la vérité de l'Art commence là où finit la vérité de la vie. Le réalisme n'a pas de droit de citoyen dans notre pays" (2003, I3I6); ou o criacionismo da década de I930, já enriquecido com o materialismo

3 "Qué hicisteis vosotros gidistas, / intelectualistas, rilkistas, / misterizantes, falsos brujos / existenciales, amapolas / surrealistas encendidas / en una tumba, europeizados / cadáveres de la moda, / pálidas lombrices del queso / capitalista, qué hicisteis / ante el reinado de la angustia, / frente a este oscuro ser humano, / a esta pateada compostura, / a esta cabeza sumergida / en el estiércol, a esta esencia / de ásperas vidas pisoteadas? // No hicisteis nada sino la fuga: / vendisteis hacinado detritus, / buscasteis cabellos celestes, / plantas cobardes, uñas rotas, / «Belleza pura», «sortilegio», / obra de pobres asustados / para evadir los ojos, para / enmarañar las delicadas / pupilas, para subsistir / con el plato de restos sucios / que os arrojaron los señores, / sin ver la piedra en agonía, / sin defender, sin conquistar, / más ciegos que las coronas / del cementerio, cuando cae / la lluvia sobre las inmóviles / flores podridas de las tumbas.” (I950, 23I)

4 "Altazor sería el resultado final de ensayos escriturales que habrían surgido en contrapunto con el creacionismo y también con otras formas, tradicionales y vanguardistas, de hacer poesía.” (Schopf, 2003, I493)

206 
histórico e com a própria crítica mariateguiana - Huidobro vai afirmar que a obra de arte criada em todas as suas partes, aquela que o criacionismo sempre buscou, inevitavelmente será uma fala sobre o mundo, todavia livre dos reducionismos da arte proletária. A composição de Altazor está enraizada bem no limiar dessa mudança de enfoque do autor e, sem dúvida, influiu para ela e foi influída por ela.

A partir daqui, pode-se pensar mais adequadamente a ideia da "pura palabra" de Altazor. Não se trata de uma palavra purificada de mundo, mas de uma palavra purificada de ornamentos, "limpia de joyas" e até mesmo purificada de imagens - um ritual de vocábulos sem sombra, porque as palavras, por si sós, têm demasiada carga. Esta "pura palabra" fala do mundo, mas sua relação com o referente é tão de vida e morte, ela está tão purificada da mera retórica, que, ao leitor desatento ou corrente, ela passará apenas, e não sem enfado, como um jogo de palavras sem sentido - como se fosse mesmo possível um jogo de palavras sem sentido. Nos poucos versos que transcrevi mais acima, no jogo dos "comos iluminados", ao tempo em que experimenta o procedimento, o poeta, o narrador, fala: do encarceramento de árvores como pássaros (a monstruosidade do homem perante a natureza, e isto lembra o explorador norueguês que, em Ecuatorial (I9I8), trafica "raros animales / Y árboles exóti$\cos ^{\prime \prime}$ ), do enfeitiçamento de turistas como serpentes (a mais-valia das viagens, a crescente locomoção do homem no mundo, cada vez mais desbotada e mascarada pelo consumismo: turistas consomem lugares, lugares consomem turistas), da aclamação, do penduricalho de reis como auroras (a fragilidade e mesmo a banalidade das instituições políticas), da crucifixão de auroras como profetas. Ou na passagem que transcrevi pouco antes, sobre a mutabilidade das imagens, quando atento a um verso como "Mientras las nubes se hacen roca", não encontro uma crítica lapidar da intoxicação do mundo levada a cabo, 
Notas sobre o caso Altazor (precedidas de deriva teórica)

Daniel Glaydson Ribeiro

sobretudo desde pouco mais de duzentos anos, pelo homem? O poeta teme que as nuvens se petrifiquem (em última instância, que não haja mais água, senão pedra), como se petrificaram os parisienses em La próxima (I934) ${ }^{5}$ por culpa de um gás tóxico, e como também os peixes estão se petrificando naqueles versos do Canto V, citados outrora: "Se abre la tumba y al fondo se ve el mar / Sube un canto de mil barcos que se van / En tanto un tropel de peces / Se petrifica lentamente".

Altazor, ao levar adiante, com a necessária distensão épica, essa experimentação com a linguagem, experimenta, por conseguinte, a própria contingência histórica do pensamento - experimenta as condições de discursar o mundo. Experimentar é levar para fora do perímetro, sacar do óbvio rumo às margens, forjar até as últimas conseqüências, que serão possivelmente a beira do ser e/ ou do nada. A viagem segue necessariamente para fora do mero sentido, ou do fácil sentido, mas isso passa longe de significar para fora do mundo. O mundo só estaria "anulado" $\mathrm{em}$ Altazor se a linguagem fosse algo alheio ao mundo e o mundo pudesse ser algo alheio à linguagem. "A evocação que nomeia as coisas invoca e provoca também a saga do dizer que nomeia o mundo. O dizer confia o mundo para as coisas, abrigando ao mesmo tempo as coisas no brilho do mundo" (Heidegger, 2003, I8-I9). O hermetismo - expressão de um conflito imanente a essa saga do dizer, que gera espectros de luz em seu brilho - surge, na obra em questão, não somente da busca intensa do novo e da rejeição da arte de propaganda, mas do próprio conflito externo em que o poema está radicado

5 Há um diálogo latente entre estas obras do poeta e romancista Vicente Huidobro.

6 E isto segundo Ramón Xirau: "Por sua intenção épica - mesmo tratando-se apenas de uma épica mental e subjetiva -, Altazor é irmão de Anábasis, The Waste Land, Narciso ou Muerte sin fin. Anulado o mundo, Altazor constitui a épica - e o drama - de uma consciência solitária” (I986: 47). Concordo com as irmandades postuladas pelo filósofo mexicano, mas em nenhuma delas leio "apenas uma épica mental e subjetiva" (como se isto fosse mesmo pouco), onde o mundo possa estar "anulado".

208 
- a tensão entre uma grande guerra e a certeza da outra por vir, entre ditaduras e revoluções, entre afasia e grito. Aquilo que é hermético fecha em si, consciente ou inconscientemente, um dizer, alguma legibilidade. Sua tensão é parte do ato:

Contempla al huérfano que se paró en su edad

Por culpa de los ríos que llevan poca agua

Por culpa de las montañas que no bajan

Crece crece dice el violoncelo

Como yo estoy creciendo

Como está creciendo la idea del suicidio en la bella jardinera

Crece pequeño zafiro más tierno que la angustia

En los ojos del pájaro quemado

Creceré creceré cuando crezca la ciudad

Cuando los peces se hayan bebido todo el mar

Los días pasados son caparazones de tortuga

Ahora tengo barcos en la memoria

Y los barcos se acercan día a día

Oigo un ladrido de perro que da la vuelta al mundo

En tres semanas

Y se mueren llegando $(1931,78)$

O órfão, mencionado desde o "Prefácio" e que é o próprio Altazor, "héme aquí solo, como el pequeño huérfano de los naufragios anónimos", proponente de que "Se debe escribir en una lengua que no sea materna" (I93I, II), cercado de um lado por enormes montanhas e do outro, pelo mar, que tem barcos na memória e que ironiza quanto a seu crescimento se este depende de uma urbanização já expressamente criticada - "Habrá ciudades grandes como un país / Gigantescas ciudades del porvenir / En donde el hombre-hormiga será una cifra / Un número que se mueve y sufre y baila / (Un poco de amor a veces como un arpa que hace olvidar / la vida)" (I93I, 35) -; este órfão é um símbolo do Chile natal. Simbologia 
Notas sobre o caso Altazor (precedidas de deriva teórica)

Daniel Glaydson Ribeiro

tão adequada para os países explorados da América, que também a utiliza Octavio Paz em El laberinto de la soledad (I950): “De ahí que el sentimiento de orfandad sea el fondo constante de nuestras tentativas políticas $y$ de nuestros conflictos íntimos. México está tan solo como cada uno de sus hijos" (1992, 79). Do outro lado do diálogo, o violoncelo. Em Huidobro, os instrumentos musicais típicos do Ocidente e seus executores aparecem como um símbolo, ou um significante (na língua do livro), para o explorador, civilizado, burguês. Um forte exemplo se encontra em Ecuatorial: "Junto a la puerta viva / El negro esclavo / abre la boca prestamente / Para el amo pianista / Que hace cantar sus dientes" (2003, 500). No Canto VI, os símbolos reaparecem numa condensação abissal: “Muerte de joya y violoncelo / Así sed por hambre o hambre y sed" (I93I, I02).

Desde o Canto IV, a cruzada já não se detém no combate aos hereges, para ater-se em sua própria e sagrada busca - vencidas as heresias, o grande poeta se concentra na busca do santo cálice: a outra linguagem. Para tanto, "No hay tiempo que perder" (I93I, 6I). O poeta leva adiante intensos rituais de desmembramento e redistribuição das palavras: estrofes repetem os mesmos termos em disposições completamente distintas; palavras são fundidas e abre-se nelas um espaço para caldear outras; destes pedaços, destas montagens, brotam novos signos; substantivos se verbalizam, verbos se substantivam (a indistinção entre o designar e o fazer é um passo nítido rumo à origem comum da linguagem e do mito). A típica genealogia de nomes, tão comum às bíblias religiosas (e aos poemas épicos), também se faz presente, mas agora os nomes se inscrevem não a partir do nascimento, como era mister, mas a partir da morte - o poeta lista inscrições tumulares, até chegar ao seu próprio epitáfio: “Aquí yace Altazor, azor fulminado por la altura / Aquí yace Vicente antipoeta y mago" (I93I,72). A cruzada (o vôo/a queda/a navegação/o experimento) busca a totalidade, e isso se deixa dizer quase de modo prosaico.

210 
CARACOL 3 / VÁRIA

\author{
No hay tiempo que perder \\ $Y$ si viene el instante prosaico \\ Siga el barco que es acaso el mejor. \\ Ahora que me siento $y$ me pongo a escribir \\ ¿Qué hace la golondrina que vi esta mañana \\ Firmando cartas en el vacío? \\ Cuando muevo el pie izquierdo \\ ¿Qué hace con su pie el gran mandarín chino? \\ Cuando enciendo un cigarro \\ ¿Qué hacen los otros cigarros que vienen en el barco? \\ ¿En dónde está la planta del fuego futuro? \\ Y si yo levanto los ojos ahora mismo \\ ¿Qué hace con sus ojos el explorador de pie en el polo? \\ Yo estoy aquí \\ ¿En dónde están los otros? \\ Eco de gesto en gesto \\ Cadena electrizada o sin correspondencias \\ Interrumpido el ritmo solitario \\ ¿Quiénes se están muriendo y quiénes nacen \\ Mientras mi pluma corre en el papel? $(1931,64)$
}

No Canto V, intensifica-se a outrora anunciada "bella locura en la zona del lenguaje" - nele está o diálogo entre o órfão e o violoncelo -, até que o cavaleiro ungido Altazor se depara com o grande moinho de vento, que faz cessar toda pretensa ilusão de que o jogo ora levado a cabo com a linguagem estaria "fuera del tiempo" (I93I, 59, 84). O jogo está na verdade sendo triturado lentamente pelas mós - e mesmo assim, e só assim, ele narra o tempo. Depois do embate de sete páginas com o moinho (a cruzada de Altazor é algo quixotesca), o grande poeta se encaminha definitivamente para a totalidade, por meio de sua diluição nas coisas. O sujeito épico plasma a natureza ao tempo em que é plasmado por ela. 
Notas sobre o caso Altazor (PRECEDIdAs de deRIVA teórica)

Daniel Glaydson Ribeiro

Y he aqui que ahora me diluyo en múltiples cosas

Soy luciérnaga y voy iluminando las ramas de la selva

Sin embargo cuando vuelo guardo mi modo de andar

Y no sólo soy luciérnaga

Sino también el aire en que vuela

La luna me atraviesa de parte a parte

Dos pájaros se pierden en mi pecho

Sin poderlo remediar.

Y luego soy árbol

Y en cuanto a árbol conservo mis modos de luciérnaga

$Y$ mis modos de cielo

$Y$ mi andar de hombre mi triste andar

Ahora soy rosal y hablo con lenguaje de rosal

$Y$ digo

Sal rosa rorosalía

Sal rosa al día

Salía al sol rosa sario

Fueguisa mía sonrodería rososoro oro

Ando pequeño volcán del día

Y tengo miedo del volcán

Mas el volcán responde

Prófugo rueda al fondo donde ronco

Soy rosa de trueno y sueno mis carrasperas

Estoy preso y arrastro mis propios grillos

Los astros que trago crugen en mis entrañas

Proa a la borrasca en procesión procreadora

Proclamo mis proezas bramadoras

Y mis bronquios respiran en la tierra profunda

Bajo los mares y las montañas.

Y luego soy pájaro

Y me disputo el día en gorgeos

El día que me cruza la garganta

212 


\author{
Ahora solamente digo \\ Callaos que voy a cantar \\ Soy el único cantor de este siglo \\ Mío mío es todo el infinito \\ Mis mentiras huelen a cielo \\ Y nada más \\ Y ahora soy mar \\ Pero guardo algo de mis modos de volcán \\ De mis rnodos de árbol de mis modos de luciérnaga \\ De mis modos de pájaro de hombre $y$ de rosal \\ $Y$ hablo como mar $y$ digo \\ De la firmeza hasta el horicielo \\ Soy todo montalas en la azulaya \\ Bailo en las volaguas con espurinas \\ Una corriela tras de la otra \\ Ondola en olañas mi rugazuelo \\ Las verdondilas bajo la luna del selviflujo \\ Van en montonda hasta el infidondo \\ Y cuando bramuran los hurafones \\ Y la ondaja lanza a las playas sus laziolas \\ Hay un naufundo que grita pidiendo auxilio \\ Yo me hago el sordo \\ Miro las butraceas lentas sobre mis tornadelas \\ La subaterna con sus brajidos \\ Las escalolas de la montasca \\ Las escalolas de la desonda \\ Que no descansan hasta que roen el borde de los altielos \\ Hasta que llegan al abifunda \\ En tanto el pirata canta \\ Y yo lo escucho vestido de verdiul \\ La lona en el mar riela \\ En la luna gime el viento \\ $Y$ alza en blanco crugimiento
}


Notas sobre o caso Altazor (PRecedidas de deriva teórica)

Daniel Glaydson Ribeiro

\author{
Alas de olas en mi azul \\ El mar se abrirá para dejar salir los primeros náufragos \\ Que cumplieron su castigo \\ Después de tantos siglos y más siglos \\ Andarán por la tierra con miradas de vidrio \\ Escalarán los montes de sus frases proféticas \\ Y se convertirán en constelaciones \\ Entonces aparecerá un volcán en rnedio de las olas \\ Y dirá yo soy el rey \\ Traedme el harrnonio de las nebulosas \\ Y sabed que las islas son las coronas de mi cabeza \\ Y las olas mi único tesoro \\ Yo soy el rey (1931, 94-97)
}

ESTA DILUIÇÃo DO SUJEITo em múltiplas coisas, que se realiza como um atravessar-se de linguagens ${ }^{7}$, faz vigorar o elo perdido da ingênua integração entre physis e logos - e, todavia, já parece ser desde a própria Natureza que o Homem aprende a cobiçar a dominação: o estranho vínculo que há entre a potência da língua e o discurso ditatorial ou tirânico. Na longa, mas sublime, passagem transcrita acima: quando a rosa fala, sua voz é toda singeleza e música; quando o mar fala, sua voz é toda uma reviravolta de palavras fundidas, densas e originais (o ruído do mar é a origem em si, como sabemos desde o Prefácio); mas quando o vulcão fala, sua voz é a própria vontade de poder. Tal anseio

7 Dentre as vozes da natureza que atravessam Altazor, também surgem, transcriadas, vozes de outros poetas. No caso, do espanhol José de Espronceda e sua famosa "Canción del pirata”, o trecho: "La luna en el mar riela, / en la lona gime el viento / y alza en blando movimiento / olas de plata y azul." (3 Goic, I974, 219).

8 Como demonstra Ernst Cassirer em Linguagem e mito (Sprache und Mythos - Ein Beitrag zum Problem der Gatternamen, I924): “O pensamento (mítico) não se coloca livremente diante do con-- 
monárquico logo contamina o pássaro-poeta: "Soy el único cantor de este siglo / Mío mío es todo el infinito / Mis mentiras huelen a cielo / Y nada más".

A totalidade e a objetividade altazorianas não se alinham às concepções racionais destes termos, mas, talvez pelo contrário, às suas ideações míticas. Enquanto o pensamento racional se detém no objeto apenas o tempo suficiente para transformá-lo em conceito, e logo o esquece, para continuar a viver clara e decididamente num mundo de verdades conceituais, o pensamento mítico pre-fere repousar no objeto, sem nem mesmo saber se é um objeto ou um sujeito aquilo em que repousa; ele entra em contato, quer ser "'possuído"” por ele e flutuar junto dele, na inconstância9.

Assim faz Altazor com as palavras, sobretudo a partir do Canto VI. O extremo estreitamento, a compreensão intensiva da linguagem. "Anudado/ noche/ nudo". Em repouso e possesso, o corpo desabrochado na natureza (da linguagem). "Viento flor /lento nube lento". Um retorno ao sincretismo semiótico; para

teúdo da percepção a fim de relacioná-lo e compará-lo com outros, através da reflexão consciente, mas, colocado diretamente perante esse conteúdo, é por ele subjugado e aprisionado. Repousa sobre ele; só sente e conhece a sua imediata presença sensível, tão poderosa que diante dela tudo o mais desaparece. Para a pessoa que esteja sob o encanto desta intuição mítico-religiosa, é como se nela o mundo inteiro afundasse. O respectivo conteúdo momentâneo, ao qual se atrela o interesse religioso, preenche completamente a consciência, de modo que nada mais subsiste junto ou fora dele. Com a máxima energia, o eu está voltado para este único objeto, vive nele e perde-se em sua esfera. Aqui reina, por conseguinte, em vez do alargamento da percepção, o seu mais extremo estreitamento; em lugar de uma expansão que poderia conduzi-la sempre a novas esferas do ser, vemos o impulso para a concentração; em lugar de sua distribuição extensiva, sua compreensão intensiva. Nesta reunião de todas as forças em um só ponto reside o pré-requisito de todo pensar mítico e de toda enformação mítica. Se, de um lado, o eu se entrega inteiramente a uma impressão momentânea, sendo por ela 'possuído'; se, de outro, há maior tensão entre o sujeito e o seu objeto, o mundo exterior; se a realidade externa não é simplesmente contemplada e percebida, mas se acomete o homem repentina e imediatamente, no afeto do medo ou da esperança, do terror ou dos desejos satisfeitos e libertos, então, de alguma forma salta a faísca: a tensão diminui a partir do momento em que a excitação subjetiva se objetiva, ao se apresentar perante o homem como um deus ou um demônio" (2006, 52-53).

9 Mais próximas duma ideação mítica que de uma concepção racional são: tanto a ideia da objetidade heideggeriana, a certa modificação da presença das coisas, quanto o termo composto de Friedrich Schlegel, o subjetivo-objetivo. 
Notas sobre o caso Altazor (PRECEDIdAs de deRIVA teórica)

Daniel Glaydson Ribeiro

que se dê um retorno dessa natureza, talvez tenha sido preciso, realmente - e isso da parte do grande poeta -, o esquecimento. "Pour qu'il y ait retour, en effet, il faut, d'abord, qu'il $y$ ait eu oubli, non pas oubli accidentel, non pas recouvrement par quelque incompréhension, mais oubli essentiel et constitutif' (Foucault, I994, 808). O retorno do grande poeta à palavra, à palavra em si mesma, o faz recordar as origens míticas dela, passando inclusive pela origem da cisão, pela quebra da universalidade - e sua referência, a grande referência de Altazor, é bíblica.

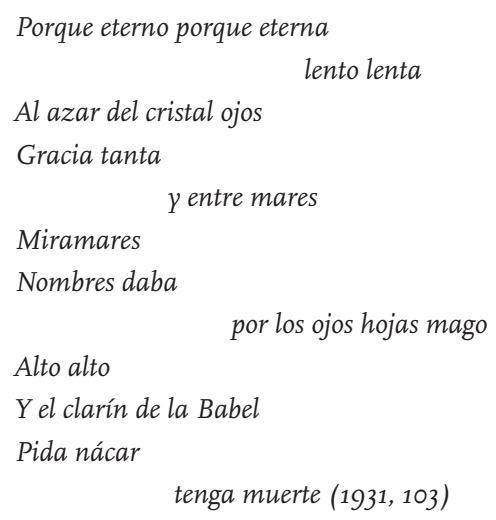

O extremo estreitamento de Altazor vai além e adentra na própria palavra, rumo a seu constituinte básico: a sonoridade, "a pura formação-em-um do infinito no finito", conforme a definição de Schelling. O grande poeta entra em transe, pois afinal, depois da "Carne labrada por arados de angustia" (I93I, 22), depois de toda uma cruzada contra a poesia - desde o início uma intervenção e uma inversão, já que sua paródia entra em cena quando os rapsodos e também os apóstolos interrompem o canto; desde o início a fissura entre o som e o sentido; desde sempre um contracanto -, ele encontra enfim a outra linguagem. 
CARACOL 3 / VÁRIA

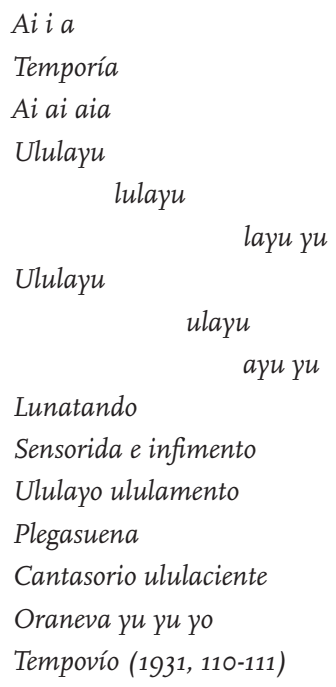

A voz de Octavio Paz foi a primeira a se levantar contra a crítica, geralmente norte-americana, que pretendia canonizar uma interpretação da viagem altazoriana como sendo a afirmação da derrota da linguagem, devido à "ausência de sentido" do último Canto. Paz lê, por bem outro lado, uma ascensão de Altazor rumo ao êxtase, que resultaria no falar em línguas mítico-religioso, conhecido pela linguística como glossolalia. Este ritual sonoro tem uma origem insondável e é muito possível que esteja no berço da própria linguagem (imagino a vontade de ter-lugar na sinfonia natural da selva). Em A sociedade contra o Estado (La société contre l'État - Recherches d'anthropologie politique, I974), Pierre Clastres fala do canto dos caçadores guaiaqui, quando os homens reunidos junto ao fogo iniciam um dialógico falar em línguas, composto, nos termos do antropólogo, por "palavras precoces, como respostas a questões que elas precederiam sempre" $(1978,72)$. Isso lembra muito o caráter mítico do grande 
Notas sobre o caso Altazor (precedidas de deriva teórica)

Daniel Glaydson Ribeiro

poeta, exatamente aquele "inatingível e inacessível" que encontrou "a resposta antes que a marcha do espírito na história permitisse formular a pergunta", como diz, repito, Lukács.

No mesmo texto em que Paz fala da glossolalia, de Altazor e, ao fim, do budismo, ele também se detém, com idêntica admiração, na teoria linguística de Benjamin Lee Whorf, a qual afirma que

\footnotetext{
Em seu nível mais alto - também o mais profundo, na base e na cúspide -, "as configurações lingüísticas ultrapassam e controlam o aspecto lexical da linguagem... Os entendimentos superiores percebem símbolos sem referências concretas a isto ou aquilo, como cheques em branco que podem ser preenchidos quando e como seja necessário e que podem significar qualquer valor de magnitude variável..." Assim, a referência “é a parte menor do sentido, e o poder configurativo a maior". A língua desemboca numa linguagem para além dos léxicos, das referências e dos significados. O sentido não se evapora, mas é irredutível à significação: é uma forma. (Paz, I99I, 42-43)
}

No espaço da linguagem altazoriana, o surgimento destas novas palavras remete ao surgimento de um novo mundo. O Canto VII provoca um estranho sentir, que nos convoca a uma escuta ávida por torná-lo comunicante, seja pelos pedaços de palavras "reais" que carrega, seja pela sonoridade que por si só fala, acima de qualquer arbitrariedade (a des-hierarquização da voz). Assim, as palavras nos invocam, a partir da nova forma, um novo, outro, sentido ou simplesmente um outro sentir: sentido é representação, sentir é presentação. Ora, Wilhelm von Humboldt, um dos precursores da linguística e irmão mais velho daquele sábio viajante que influencia Sousândrade na composição d'O Guesa e aparece na narrativa experimentando um veneno indígena, já dizia: 
Altazor é a narrativa de tal pulo, de pára-quedas. Não uma escapatória, mas uma afronta bélica. Dada a historicidade intrínseca ao gênero épico, cujo fim é a representação da imanência, a linguagem de que trata o poema forçosamente se localiza, e a revolta de Altazor contra a língua materna (instalada por um colonizador) se resolve no ato revolucionário e carnavalesco de negá-la, de desconstruí-la e propor outra. As epopeias tradicionais, sempre advindas das belicosas nações de senhores que se estabelecem sobre a massa dos autóctones vencidos $^{\mathrm{Io}}$, estão localizadas num momento histórico em que o nascimento da nação se irmana com a cristalização (e a imposição, para os bárbaros) de um idioma. No limite de sua loucura - e também de sua crença, somadas uma e outra sob o signo da angústia - Altazor termina, regressa, exibindo o produto de sua viagem, seu butim de guerra: um outro sistema de sons (mesmo se o poeta não consegue romper de todo as amarras de sua língua materna, em vários aspectos), uma nova língua ou ao menos um protótipo, forjado na imaginação do início e pronunciado para um outro mundo - escritura do desejo de uma nova origem, uma nova nação, uma nova história.

Io "Os cantos de Homero e os hinos do Rigveda datam da época da dominação territorial e dos lugares fortificados, quando uma belicosa nação de senhores se estabeleceu sobre a massa dos autóctones vencidos" (Adorno; Horkheimer, I985, 24). 
Notas sobre o caso Altazor (precedidas de deriva teórica)

Daniel Glaydson Ribeiro

Para nós, que estamos ainda tão inseridos em sua problemática - o problema, o mito do nosso tempo é a linguagem, e isso o comprovam tanto um racionalista como Cassirer, quanto um "irracionalista” como Heidegger, sem falar em Derrida etc. -, Altazor soa demasiadamente mitológico (um estudo sobre o problema, sobre o mito), mas, ao longo dos mil anos em que o poema promete povoar os sonhos dos homens, é extremamente possível que a obra vá ganhando, cada vez mais e mais, a sua devida envergadura mítica (de culto e profanação do mito).

\section{REFERÊNCIAS BIBLIOGRÁFICAS}

Adorno, Theodor. Notas de literatura I. São Paulo: Duas Cidades; Editoria 34, 2003.

Adorno, Theodor. Horkheimer, Max, Dialética do esclarecimento: fragmentos filosóficos. Rio de Janeiro: Jorge Zahar, I985.

Agamben, Giorgio. Profanações. São Paulo: Boitempo, 2007.

Auerbach, Erich. Mimesis: a representação da realidade na literatura ocidental. São Paulo: Perspectiva, I97I.

Cassirer, Ernst. Linguagem e mito. São Paulo: Perspectiva, 2006.

Clastres, Pierre. A sociedade contra o Estado: pesquisas de antropologia política. Rio de Janeiro: F. Alves, I978.

Costa, Rene de. Huidobro: los oficios de un poeta. México D.F.: FCE, I984.

Feuerbach, Ludwig. A essência do cristianismo. Petrópolis: Vozes, 2007.

Foucault, Michel. “Qu'est-ce qu'un auteur?”. In: Dits et écrits. vol. I. Paris: Gallimard, I994. 
Goic, Cedomil. La poesía de Vicente Huidobro. Santiago de Chile: Nueva Universidad, I974.

Heidegger, Martin. Que é metafísica? São Paulo: Duas Cidades, I969.

A caminho da linguagem. Petrópolis: Vozes; Bragança Paulista: Ed. Universitária São Francisco, 2003.

Huidobro, Vicente. Altazor. Madrid: CIAP, I93I.

Obra poética. Barcelona: ALLCA XX, 2003.

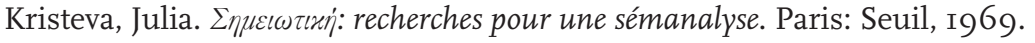

Lukács, Georg. A teoria do romance: um ensaio histórico-filosófico sobre as formas da grande épica. São Paulo: Duas Cidades, Ed. 34, 2000.

Mariátegui, José Carlos. "Arte, revolución y decadencia”. In: Ensayos escogidos. Lima: Universo, I974.

Neruda, Pablo. Canto General. México D.F.: Talleres Gráficos de la Nación, I950.

Paz, Octavio. Convergências: ensaios sobre arte e literatura. Rio de Janeiro: Rocco, I99I.

El laberinto de la soledad. México D.F.: FCE, I992.

"Decir sin decir: Vicente Huidobro". In: Obras completas: Fundación y disidencia - dominio hispánico. vol. 3. México D.F.: FCE, I994.

Ricoeur, Paul. Tempo e narrativa - Tomo III. Campinas: Papirus, I997.

Schelling, Friedrich. Filosofia da Arte. São Paulo: Ed. da USP, 200 I.

Schopf, Federico. "Lectura de Altazor". In: Huidobro, Vicente. Obra poética. Barcelona: ALLCA XX, 2003. 